\title{
Habitat Use by Pseudochondrostoma duriense and Squalius carolitertii Downstream of a Small-Scale Hydropower Plant
}

\author{
Isabel Boavida ${ }^{1, *(\mathbb{D})}$, Filipa Ambrósio ${ }^{2}$, Maria João Costa ${ }^{1}\left(\mathbb{D}\right.$, Ana Quaresma ${ }^{1}$ (D), \\ Maria Manuela Portela ${ }^{1}$, António Pinheiro ${ }^{1}$ (D) and Francisco Godinho ${ }^{3}$ \\ 1 CERIS, Civil Engineering Research and Innovation for Sustainability, Instituto Superior Técnico, \\ University of Lisbon, 1049-001 Lisbon, Portugal; mariajcosta@tecnico.ulisboa.pt (M.J.C.); \\ analopesquaresma@tecnico.ulisboa.pt (A.Q.); maria.manuela.portela@ist.utl.pt (M.M.P.); \\ antonio.pinheiro@tecnico.ulisboa.pt (A.P.) \\ 2 Instituto Superior Técnico, University of Lisbon, 1049-001 Lisbon, Portugal; \\ filipa.brown.ambrosio@gmail.com \\ 3 Hidroerg, Projectos Energéticos, Lda, 1300-365 Lisbon, Portugal; francisco.godinho@hidroerg.pt \\ * Correspondence: isabelboavida@tecnico.ulisboa.pt
}

Received: 24 July 2020; Accepted: 5 September 2020; Published: 9 September 2020

\begin{abstract}
Downstream of small-scale hydropower plants (SHPs), the intensity, frequency and persistence of hydropeaking events often cause an intolerable stress on fish of all life stages. Rapid increases in flow velocity result in fish avoiding unstable habitats and seeking refuge to reduce energy expenditure. To understand fish movements and the habitat use of native Iberian cyprinids in a high-gradient peaking river, 77 individuals were PIT tagged downstream of Bragado SHP in the North of Portugal. Tagged fish species included Pseudochondrostoma duriense and Squalius carolitertii. Fish positions were recorded manually on two different occasions: during hydropeaking events (HP) and without hydropeaking events (NHP). From the 77 tagged fish, we were able to record habitat use for 33 individuals (20 P. duriense and $13 \mathrm{~S}$. carolitertii) in a total of 125 relocations. Fish species were distributed along the river reach with high density in the upstream area in the vicinity of the SHP tailrace, in particular during HP. Fish locations were associated with velocity for P. duriense and S. carolitertii. The latter tended to use faster flowing waters than $P$. duriense. Our findings on the habitat use in peaking rivers are a valuable tool to help in the selection and design of mitigation measures.
\end{abstract}

Keywords: cyprinids; small hydropower plant; hydropeaking; peaking rivers; habitat use

\section{Introduction}

The recent boost of clean energy sources, such as wind and solar, and their foreseeable increase in the near future, relies on the possibility of being replaced when needed. Hydropower maintains a prominent position amongst renewables [1] while being able to quickly replace solar and wind and respond to electricity demand, thus contributing to reduce $\mathrm{CO}_{2}$ emissions and help cope with climate change. Consequently, the interest in hydropower generation has regained general attention [2,3]. In Europe, hydropower development is massive with a total of 30,172 plants, out of which, 8507 are planned and 278 are under construction [4]. There is a large dominance of small-scale hydropower projects (SHP) $(<10 \mathrm{MW})$ [5], mainly as a consequence of the limited capacity of many countries to still accommodate large hydropower projects.

The damaging impacts of hydropower plants on ecosystems are relatively well studied for large hydropower dams [6,7], due to their size and position in the river network. However, little attention has been paid to the effects of SHP [8], with most studies focusing on the impacts of low flow in 
bypassed river reaches due to SHP water diversion $[9,10]$. SHP may produce extensive ecological impact because they are numerous, thus exacerbating ongoing habitat fragmentation and disturbing the ecological river integrity [10,11], while only contributing marginally to electricity production [4]. The impacts of SHP per megawatt of power produced may be disproportionally higher than that of large hydropower plants [12]. Their small size, resulting from their small watershed, allows them to be built in more remote areas where the ecosystems typically support unique and endemic fauna and flora adapted to thrive in these environments [9].

The rapid flow variations that may be generated by hydropower facilities-i.e., water pulses called hydropeaking [13] — have a serious impact in many riverine ecosystems, particular on fish [14], raising concerns as to the ability of fish to respond to peaking events, and the costs and time to react to constant changes [15]. In the past decade, several studies have been published in an attempt to assess the hydropeaking impacts by investigating swimming responses [15], feeding activity [16], growth rates and inter- and intraspecific competition [17], spawning and migration activity [18], and habitat use [19]. Regarding the latter, different responses have been reported. When exposed to peak flows, fish will probably move laterally to "recolonize" abandoned habitats [6], will seek out short-term refuge, rendering them prone to stranding on later downramping [20], will potentially move downstream to more suitable habitats [21], or will be forced to move between feeding zones and refuges [22]. The wide spectrum of fish responses, influenced by fish ecology and site-specificity, restricts an understanding of the effects of hydropeaking on freshwater fish.

Physical factors, usually described by water velocity and depth [23], substrate size and composition [24], are generally more predictable, less variable and more easily measured than biological and chemical ones [25]. Velocity and depth used by different fish species are widely available in the literature, whereas there is still lack of information on fish species preferences for turbulence parameters which strongly influence fish behavior [26-28]. Rapid flow changes reduce the amount and quality of suitable habitat, and the distribution and abundance of many fish species, including Iberian small-sized cyprinids, which are strongly influenced by their habitat [29]. Fish movements in river reaches subjected to hydropeaking may be expected to be primarily a response to deteriorating habitat conditions. Probably owing to the difficulty in controlling confounding effects, the field evidence of individual responses to hydropeaking remains limited. The great majority of hydropeaking research is still restricted to experiments in indoor flumes [30,31] and outdoor experimental channels [20], rather than field studies. There is currently a lack of studies, both in experimental and field situations, that consider small-sized species.

In narrow and shallow rivers, passive integrated transponder (PIT) technology, using a portable reading unit, can also be used to a similar effect as standard radio telemetry [32]. PIT tags are a less invasive and low-cost method [33], with a detection range up to $1 \mathrm{~m}$ and a detection rate up to $80 \%$ [34]. Additionally, PIT tags allow long-term monitoring, enabling to reduce the number of tagged fish [35]. The ability to tag and monitor individual fish provides a valuable insight into fish behavior [36] downstream of an SHP, which is crucial to propose solutions to mitigate the effects of rapid flow variation and contribute to the management and conservation of aquatic biodiversity.

In Iberia, endemic rheophylic cyprinids dominate the native fish fauna [37] and are considered indicator species in the sense that they can provide early an warning of any anthropogenic change that may occur [29]. Many of these species have a protected status under IUCN (International Union for Conservation of Nature), placing the Iberian freshwater fish fauna as one of the most endangered in Europe. The present study investigates the effect of peak flows from a SHP with short-term river regulation on the habitat of Iberian native small-sized cyprinids-Iberian straight-mouth nase Pseudochondrostoma duriense (Coelho 1985; IUCN status: vulnerable), and Iberian chub Squalius carolitertii (Doadrio 1988; IUCN status: least concern). We hypothesized that (i) cyprinids would prefer less hydropeaking-induced disturbance; (ii) habitat use patterns should shift in peaking rivers; and (iii) fish species should display differential habitat use. 


\section{Materials and Methods}

\subsection{Study Area}

This study was conducted in the Avelames River, downstream of the Bragado SHP $\left(41^{\circ} 34^{\prime} 53.27^{\prime \prime} \mathrm{N}\right.$, $7^{\circ} 40^{\prime} 50.95^{\prime \prime}$ W, c. $337 \mathrm{~m}$ a.s.1.) located in northern Portugal. The Avelames River is a tributary of the Tâmega River (Douro River basin, Figure 1) located in a remote rural area, dominated by shrub and forested areas. The Avelames River, a low-sized, third-order stream [38] runs through deposits of sand, gravel and large cobbles. The Avelames River has a pluvial run-off regime. The climate is close to a Mediterranean with continental influence, characterized by warm and dry summers and concentrated precipitation events during the autumn and spring. Inter-annual variation in discharge is also large, as is typical of a river with a Mediterranean flow regime. Long-term mean annual discharge amounts to $1.4 \mathrm{~m}^{3} / \mathrm{s}$ (watershed area of $78.8 \mathrm{~km}^{2}$ and a mean annual flow volume of $44.1 \mathrm{hm}^{3}$ ). A $150 \mathrm{~m}$ long reach representing a range of habitats was selected in the vicinity of Bragado SHP tailrace. The river reach can be divided in two sub-reaches located upstream and downstream of the powerhouse tailrace, respectively. The upstream sub-reach ends at a waterfall that blocks upstream fish movements. No other physical obstructions were found in the studied reach. The river reach includes a wide variety of habitats, from small pools to riffles and runs. Submerged boulders provide cover features, and well developed riparian vegetation provides shade. The cross-section width ranges from 3 to $10 \mathrm{~m}$, with an average longitudinal slope of 0.0332 .

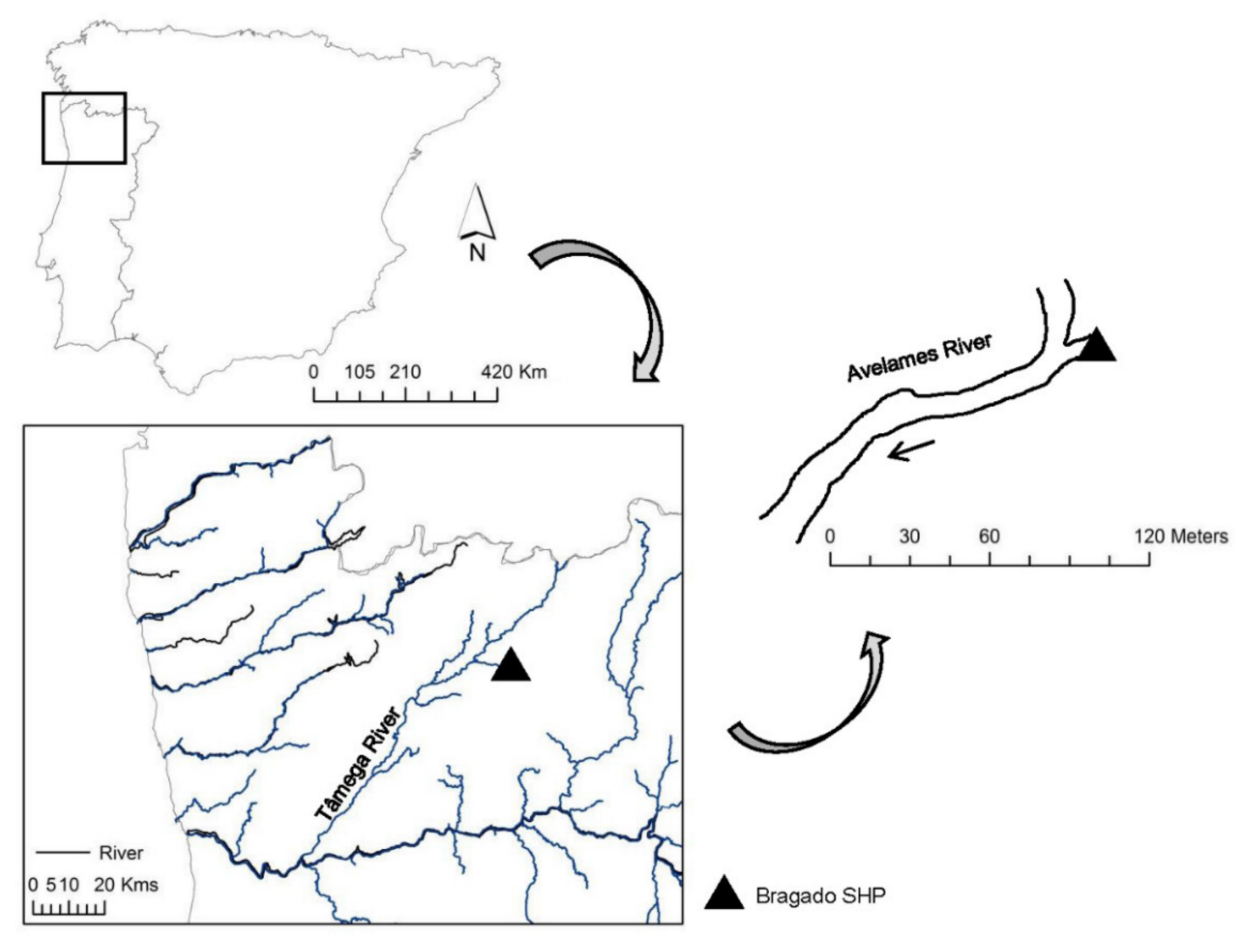

Figure 1. Avelames River and Bragado small-scale hydropower plant (SHP) location in Northern Portugal. The SHP tailrace and the selected river reach. Large arrows indicate the maps scale increase.

The powerhouse of Bragado SHP is located around $2 \mathrm{~km}$ downstream of the weir where the water intake is located. A water diversion conveyance system feeds the powerhouse, which is equipped with a Francis turbine with a horizontal shaft designed for a maximum discharge of $2.2 \mathrm{~m}^{3} / \mathrm{s}$ and a net head of $155.2 \mathrm{~m}$. The installed capacity is 3.1 MW and the mean annual electricity production is $9.0 \mathrm{GWh}$.

The fish community of the Avelames River is dominated by small-sized native cyprinids, as is typical of similar rivers in northern Portugal. Further downstream, close to the confluence with the Tâmega River, other species may be found, including the larger sized Iberian barbel (Luciobarbus bocagei). 
Further upstream, brown trout (Salmo trutta) may also be found. Migratory fish species requiring long distance movements to reproduce do not occur in this river.

\subsection{Data Collection}

The riverbed topography was surveyed from 8 to 10 of September 2017. A total of 5045 points were collected ( $\mathrm{x}, \mathrm{y}$ and $\mathrm{z}$ coordinates) along the $150 \mathrm{~m}$ Avelames reach with an accuracy adequate to define the riverbed morphology and the approximate shape of the macro-irregularities emerging from the water (e.g., boulders and large objects). Substrate composition was collected along the river reach and defined using a Wentworth scale [39]: (1) organic cover; (2) silt (1-2 mm); (3) sand (2-5 mm); (4) gravel (5-25 mm); (5) pebble (25-50 mm); (6) cobble (50-150 mm); and (7) boulder (>150 mm). Flow velocity and depth were measured in several points along five cross-sections. Depths were measured with a ruler and water velocities with a flow probe (model 801 , Valeport) positioned at $60 \%$ of the local depth below the surface.

\subsection{Telemetry}

A total of 77 cyprinids were caught on the 16 May 2018 downstream of Bragado SHP by electrofishing (Hans Grassl IG-200). Fish species included Pseudochondrostoma duriense and Squalius carolitertii. Average water temperature was $16^{\circ} \mathrm{C}$, conductivity was $50 \mu \mathrm{S} / \mathrm{cm}$ and $\mathrm{pH}$ was 7.7. After collection, the fish were kept in a $2 \mathrm{~m}$-long closed fish net in the stream for $2 \mathrm{~h}$ before being individually marked with passive integrated transponder (PIT) tags. Fish were anaesthetized with MS-222 (Tricaine Methanesulfonate) $(60 \mathrm{mg} / \mathrm{L})$ and were marked with a small HDX PIT-Tag $(12 \times 2.12 \mathrm{~mm}$ weighing $0.1 \mathrm{~g}$ from Oregon RFID) previously sterilized with ethyl alcohol $96 \%$. The weight of the transmitter was always less than $2 \%$ the recipient's body weight [40]. The tag was injected in the intraperitoneal cavity with a sterilized needle linked to a grip injector (Oregon RFID). Marking without the use of sutures to close the incision was the most appropriate PIT tagging procedure for small cyprinids. Fish were sorted by species and measured for total length (TL) and weight (TW). One hour following the insertion and after regaining equilibrium, fish were released at their capture location (next to the SHP tailrace) and left to acclimate for four days.

Fish positions were recorded during base flow on two different occasions. First, when the SHP was in operation, with peak flows every week day, for at least a month (hereafter HP-hydropeaking). The HP survey occurred right after a peak flow within the range of 0.90 to $1.90 \mathrm{~m}^{3} / \mathrm{s}$ and with a minimum of $3 \mathrm{~h}$ duration was released. During the survey, the river flow rate was within the range of $0.35-0.50 \mathrm{~m}^{3} / \mathrm{s}$. During the peak flow, the survey was unmanageable due to the intensity and magnitude of flow. Second, the survey took place when the SHP was not in operation for at least one continuous month (hereafter NHP-no hydropeaking) due to low flow. During the NHP survey the flow rate was $0.08 \mathrm{~m}^{3} / \mathrm{s}$. On each occasion, the river reach was surveyed at six different times in 2018: 6, 7, 11, 12, 18 and 19 June for HP, and 1, 2, 3, 9, 10 and 11 of October for NHP. In each survey, the operator waded in the upstream direction, sweeping the portable (Oregon high-performance HDX RFID reader, ISO 11784 compatible) and length of pole antenna (c. $50 \mathrm{~cm}$ in diameter) [41] just above the water surface from the river bank to river bank, scanning the entire river reach looking for tagged fish and avoiding disturbing the flow. Each time a fish was detected, the fish ID was registered and the fish location was recorded with a dual-frequency GNSS receiver (Trimble R2). Additionally, the water velocity and depth were measured along different cross-sections to calculate the discharge during the surveys.

All the procedures involving fish sampling were carried out according to European standards (Directive 2010/63/UE), European norms CEN EN 14011:2003 [42], and Portuguese legislation (Decree Law 113/2013 and 1/2019) and guidelines [43]. For this, a permit was issued by the Portuguese licensing entity, the Instituto da Conservação da Natureza e Florestas (ICNF). All the researchers involved with the direct manipulation of fish are authorized to carry out and design procedures and scientific projects involving animal experimentation according to Article 23: the project was authorized by the 
Portuguese authority Direção Geral de Alimentação e Veterinária (DGAV) according to Article 38, both from the European Directive 2010/63/UE. The principle of replacement, reduction and refinement (3Rs) was followed while developing the experimental protocol. No fish were sacrificed for the purpose of this study.

\subsection{Hydrodynamic Modeling}

Hydrodynamic simulations of water flow were performed using HEC-RAS (version 5.0.7) considering two-dimensional unsteady flow. The HEC-RAS 2D model was used to simulate the hydrodynamic conditions during the surveys of HP and NHP. In the HEC-RAS model, the unsteady flow simulation uses either the 2D Saint-Venant equations (often referred as the shallow water equations) or the 2D Diffusion Wave equations. The 2D Saint-Venant equations solver disregards vertical velocities and assumes hydrostatic pressure, whereas the diffusive wave approximation additionally omits unsteady advection and turbulent viscous terms. The simulation time is thus different in both equations (the 2D Diffusion Wave equations generally allow the software to run faster), however the 2D Saint-Venant equations are applicable to a wider range of problems. In the present study, the 2D Saint-Venant equations were applied. The inputs were the topography, the boundary conditions (flow hydrograph in the upstream boundaries and normal depth in the downstream boundary) and the Manning's roughness coefficient (n). The model was calibrated for a surveyed discharge and validated with the field measurements. The calibration procedure consisted of adjusting the channel roughness, i.e., Manning's coefficient, and the finite element mesh until a good agreement of simulated versus a previously calculated rating curve at the most downstream section of the studied reach [44] and the surveyed water surface elevations for the 5 cross-sections was achieved. The finite element mesh cell's minimum size was $0.1 \mathrm{~m}^{2}$ with an average of $3 \mathrm{~m}^{2}$. The best agreement between the model results, the calculated rating curve and the field campaign values was obtained considering a roughness coefficient $(n)$ ranging between 0.08 and $0.09 \mathrm{s.m} \mathrm{m}^{-1 / 3}$. A sensitivity analysis regarding the time step value was also performed. The time step value was assessed and chosen to obtain Courant numbers lower than 1 to increase model stability. The chosen values ranged between 1 and $2 \mathrm{~s}$, depending on the simulated discharge. At the end of the calibration process, the model was simulated for the discharges occurring during the surveys. Finally, the values of depth-averaged velocity (hereafter velocity) and water depth were exported to ArcGIS and integrated with the fish relocations.

\subsection{Data Analysis}

All fish locations (hereafter relocation) from the tracking data were plotted into a Geographic Information System (ArcGIS version 10.3.1). To quantify the habitat use patterns, results from the hydrodynamic modeling (maps of habitat) were exported to ArcGIS for further analysis. Fish habitat use (i.e., velocity and depth) per relocation was then calculated in ArcGIS, including a buffer of c. $1 \mathrm{~m}$ for each fish position. Values inside the buffer region include all mesh nodes previously simulated in HEC-RAS. Outliers were left out (e.g., $1 \mathrm{~m}$ buffer may include a mesh node in the buffer border corresponding to a deeper region and thus not expressing the true habitat where the fish were found) and the mean values for the hydraulic parameters (i.e., velocity and depth) were calculated to attribute a single velocity and depth value to each fish relocation. The position of the fish was recorded as DW and UP if a fish was found, respectively, downstream or upstream of the SHP tailrace. The distance to the SHP tailrace was also measured for each fish relocation. Each fish relocation was assumed to be independent because fish surveys were done every other day, therefore reducing the likelihood of consecutive points being correlated. It was also assumed that the cyprinid species were not competing for habitat or food because P. duriense is a bottom feeder, in contrast to $S$. carolitertii which feeds in the mid- to upper water column. Therefore, data analyses were always individualized by species.

To determine if there was a significant discrepancy in the fish surveyed between the two occasions-HP and NHP — that could indicate downstream displacement, a Wilcoxon-Mann-Whitney test was used to compare the total length (TL), total weight (TW) and condition factor (K). 
The environmental data for each fish relocation (i.e., velocity, depth, substrate and distance to the SHP tailrace) was submitted to a principal component analysis (PCA) [45] to determine the variables that best explain the habitat use. Before applying the PCA, the continuous variables were standardized. Only components with eigenvalues $>1$ were retained (Kaiser-Guttman Criterion). Loadings $\geq|0.50|$ were used for the interpretation of the microhabitat gradients. The PCA was performed using prcomp function from factoextra R-package (v. 1.0.6) [46].

A permutational multivariate analysis of variance (PERMANOVA) using Euclidean distance was used to search for significant differences between the two occasions-HP and NHP in fish habitat use. The following habitat variables were used: velocity, depth, substrate, distance to the SHP tailrace and fish relocation in the river reach (i.e., UP or DW the SHP tailrace). PERMANOVA does not require the assumptions of parametric tests [47], and is also a powerful test even for small sized samples [48]. The analysis was done using the vegan R-package (v 2.5-6) [49]. When a significant overall effect was detected, a detailed analysis was performed by applying the Kruskal-Wallis test.

All statistical analysis were implemented in $\mathrm{R} v$ 3.6.2 [50]. Plots were done using the ggplot2 (v. 3.2.1) [51], ggfortify (0.4.8) [52], and corrplot (v 0.84) [53] R-packages.

\section{Results}

\subsection{Telemetry}

From the 77 tagged fish, we were able to record 33 individuals (20 P. duriense and 13 S. carolitertii) in a total of 125 relocations. The detection rate was $43 \%$. During the hydropeaking (HP), one P. duriense was found dead, eaten by a snake (the tag was inside the snake) and was left out of the analysis. Overall, 15 P. duriense (TL $8.6 \pm 1.1 \mathrm{~cm}$; TW $6.6 \pm 2.7 \mathrm{~g}$ ) and 12 S. carolitertii (TL $10.0 \pm 2.4 \mathrm{~cm}$; TW $15.8 \pm 15.4 \mathrm{~g}$ ) were recorded on a total of 61 relocations during HP; and during the no hydropeaking (NHP) occasion, 14 P. duriense (TL $8.6 \pm 1.3 \mathrm{~cm}$; TW $6.8 \pm 3.1 \mathrm{~g}$ ) and seven S. carolitertii (TL $8.8 \pm 1.0 \mathrm{~cm}$; TW $7.1 \pm 4.1 \mathrm{~g}$ ) were detected in a total of 64 relocations. There were nine P. duriense (TL $8.6 \pm 1.3 \mathrm{~cm}$; TW $6.2 \pm 3.0 \mathrm{~g}$ ) and seven S. carolitertii (TL $8.8 \pm 1.0 \mathrm{~cm}$; TW $7.1 \pm 4.1 \mathrm{~g}$ ) that were recorded both in HP and NHP.

The remainder fish either: (i) were located in the study area, but may have escaped downstream while the operator with the portable antenna was moving upstream to detect fish; (ii) were located in a deep area perhaps below a boulder and the receiver was out of range, (iii) could have been eaten by animals at a higher level of the food chain, such as the European otter (Lutra lutra) [54] not spotted during the field sampling events, or (iv) could have moved longer distances downstream and left the studied reach.

The fish total length (TL) and total weight (TW) for each relocation were not significantly different between the HP and NHP occasions for P. duriense ( $\mathrm{N}=76$, TL: $p=0.160$; TW: $p=0.531$ ) and S. carolitertii $(\mathrm{N}=49$, TL: $p=0.075)$ with the exception of TW for the later species $(\mathrm{N}=49$, TW: $p=0.011)$. The condition factor was significantly different between the HP and NHP for S. carolitertii $(\mathrm{N}=49$, $p<0.001$ ) whereas for P. duriense no difference was found (Figure 2).

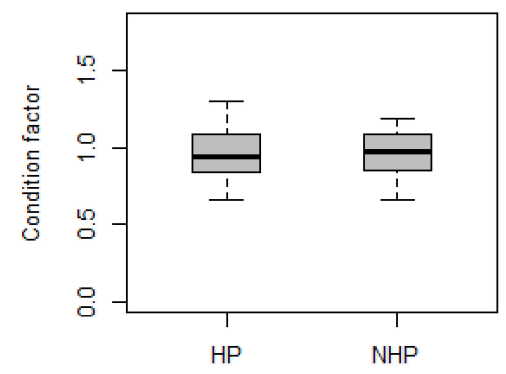

(a)

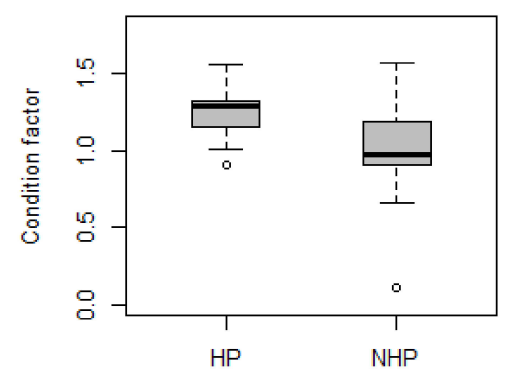

(b)

Figure 2. Boxplots of the condition factor for (a) P. duriense and (b) S. carolitertii during the hydropeaking events (HP) and without hydropeaking events (NHP) occasions. 


\subsection{Habitat Use}

Fish relocations were distributed along the river reach during the two surveys occasions-HP and NHP — with a high density in the region upstream of the SHP tailrace (Figure 3).

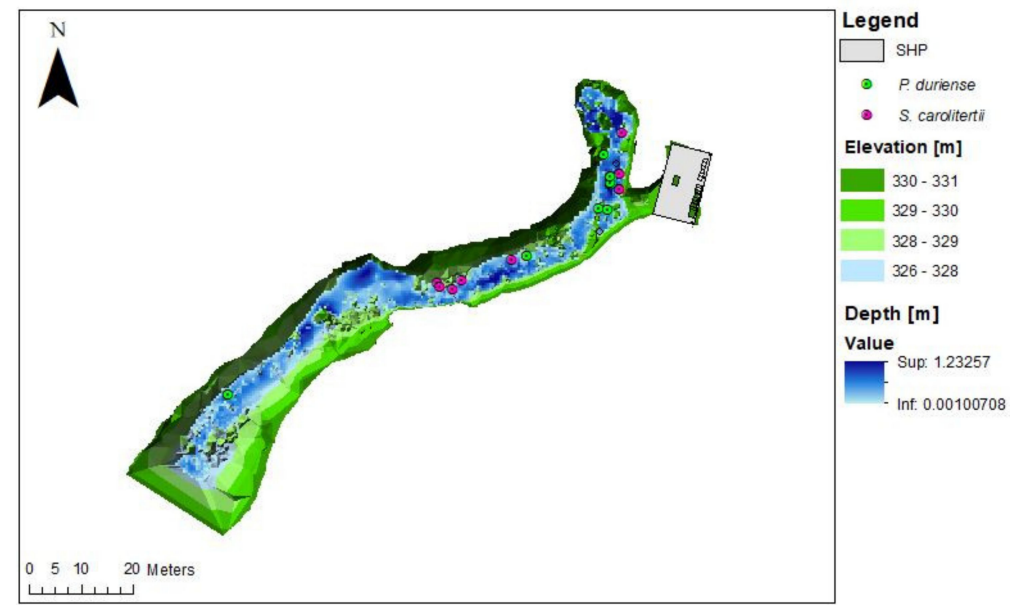

(a)

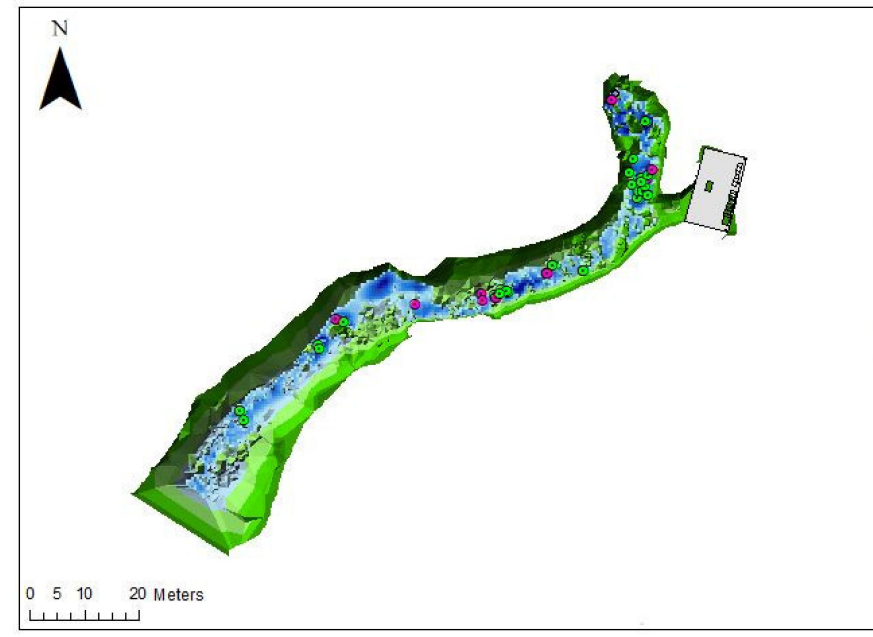

Legend

- P. duriense

- S. carditerti

Elevation [m]

330 - 331

- $329-330$

- $328-329$

326- 328

Depth [m]

Value

Sup: 1.02655

Inf. 0.00128174

(b)

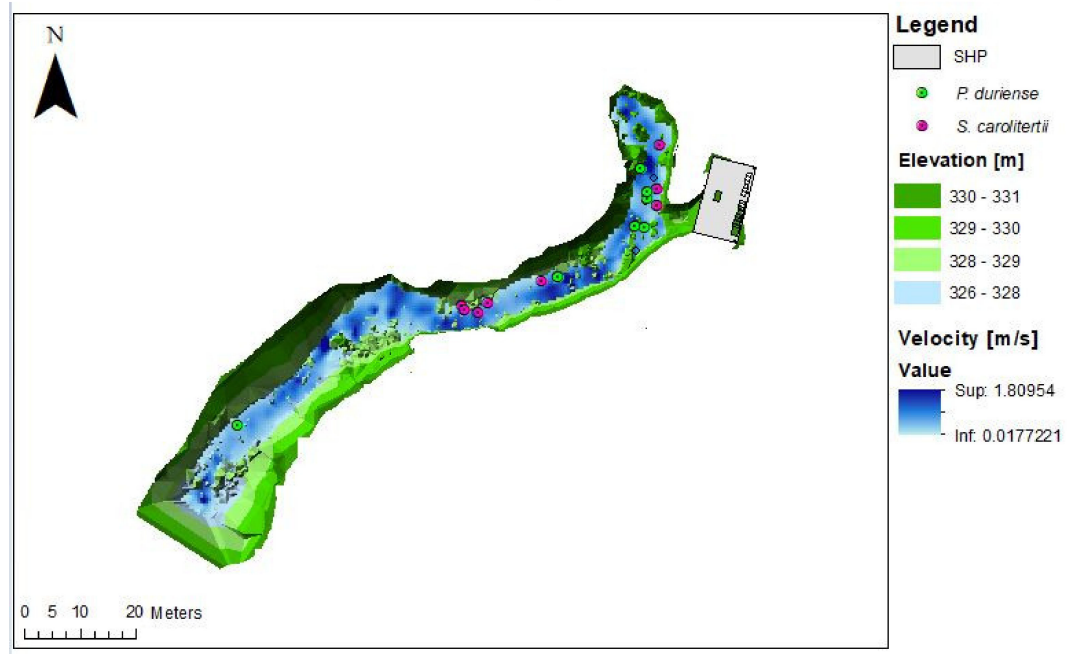

(c)

Figure 3. Cont. 


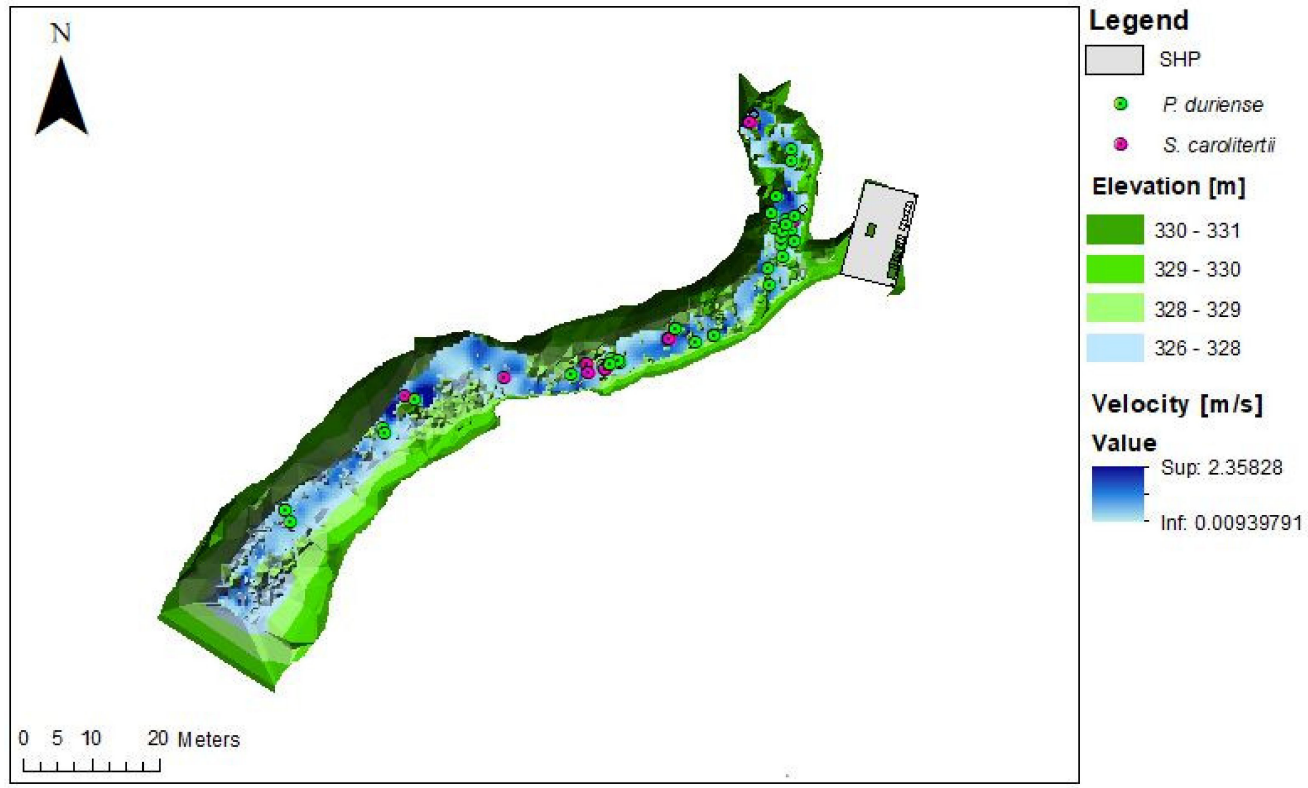

(d)

Figure 3. Fish relocations in the river reach during the surveys: (a) depth for $\mathrm{HP}\left(\mathrm{Q}=0.5 \mathrm{~m}^{3} / \mathrm{s}\right)$; (b) depth for NHP $\left(\mathrm{Q}=0.08 \mathrm{~m}^{3} / \mathrm{s}\right)$; (c) velocity for $\mathrm{HP}\left(\mathrm{Q}=0.5 \mathrm{~m}^{3} / \mathrm{s}\right)$; and (d) velocity for NHP $(\mathrm{Q}=0.08$ $\mathrm{m}^{3} / \mathrm{s}$ ). Fish relocations represent a point of $1 \mathrm{~m}^{2}$ that may contain one or more fish.

The fish relocations were evenly distributed within the two occasions (with 61 in HP and 64 in NHP) with a lower number of $S$. carolitertii detected in both survey occasions (76 and 49 relocations of P. duriense and S. carolitertii, respectively) (Table 1).

Table 1. Number of fish relocations by species detected in the river reach (downstream and upstream of the tailrace) during $\mathrm{HP}$ and NHP occasions.

\begin{tabular}{ccccc}
\hline & \multicolumn{2}{c}{ Downstream } & \multicolumn{2}{c}{ Upstream } \\
\hline & HP & NHP & HP & NHP \\
\hline P. duriense & 17 & 17 & 17 & 25 \\
S. carolitertii & 13 & 10 & 14 & 12 \\
\hline
\end{tabular}

A total of 57 and 68 fish relocations were detected DW and UP the SHP tailrace, respectively (Table 1). The distances at which each fish was found in relation to the tailrace are shown in Figure 4. During NHP there is a tendency for both species to use the entire channel in comparison to the HP occasion. Only P. duriense was found in the section immediately downstream of the SHP tailrace after a peak event occurred (HP occasion), whereas no S. carolitertii were found in the $20 \mathrm{~m}$ below the SHP tailrace, although they used the section from 20 to $50 \mathrm{~m}$ distance of the tailrace. In general, during NHP, the fish tend to spread their habitat use along the river longitude, particularly P. duriense, which were also found in the most downstream region of the studied reach (i.e., 70 to $100 \mathrm{~m}$ distance to the SHP tailrace), where $S$. carolitertii was never found. 
(a)

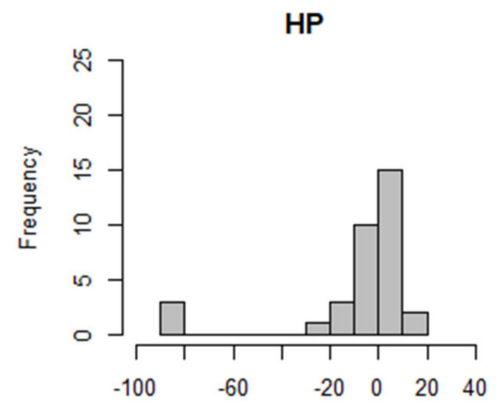

(b)

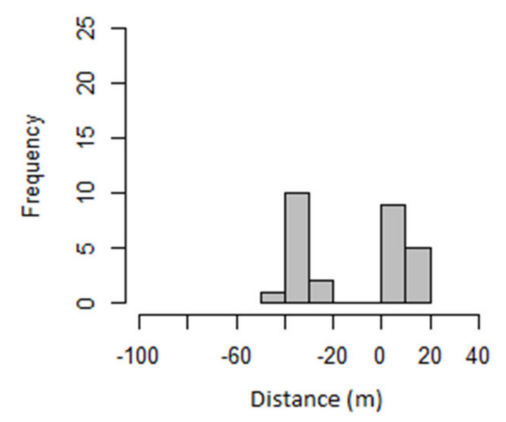

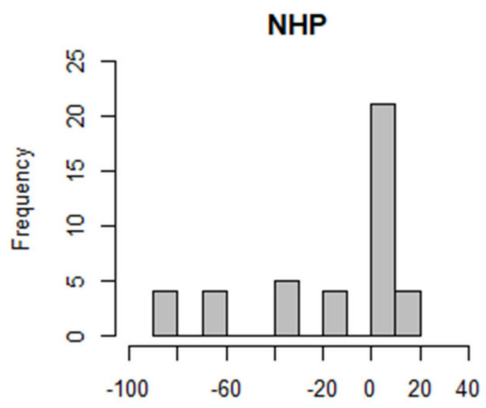

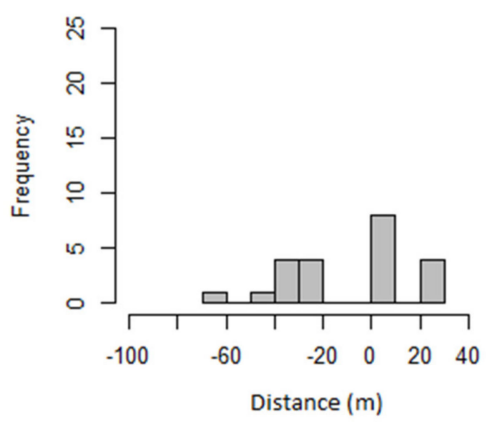

Figure 4. Histograms of frequency in relation to distance to the SHP tailrace of each fish relocation for (a) P. duriense during HP $(\mathrm{N}=34)$ and NHP $(\mathrm{N}=42)$ occasions; and for $(\mathbf{b})$ S. carolitertii during HP $(\mathrm{N}=27)$ and NHP $(\mathrm{N}=22)$ occasions. Positive and negative values correspond to fish relocations down and upstream, respectively, in relation to the SHP tailrace.

The standardized distances to the SHP tailrace of the upstream fish relocations were similar in $\mathrm{HP}$ and NPH for $P$. duriense $(\mathrm{N}=42 ; p=0.450)$ and $S$. carolitertii $(\mathrm{N}=26, p=0.258)$, in contrast to the downstream fish relocations where the standardized distances for both species were significantly different ( $P$. duriense $\mathrm{N}=34$ and $S$. carolitertii $\mathrm{N}=23 ; p<0.05$ ) for HP and NHP. The standardized distances DW and UP the SHP tailrace for both P. duriense and S. carolitertii were significantly different in the HP occasion ( $\mathrm{W}=62.5, p=0.005$ and $\mathrm{W}=143.5, p=0.012$, respectively). When there was no hydropeaking, during NHP, no significant differences were found $(p>0.05)$ in the standardized distances of fish relocations to the tailrace between downstream and upstream areas.

Boxplots of habitat use (i.e., depth and velocity) for P. duriense and S. carolitertii in the two different occasions-HP and NHP-are shown in Figure 5.

As expected, for HP, the values of velocity for both species were significantly higher $(p<0.001$; Mann-Whitney U) than in NHP; no significant differences were found for water depth. Among species, S. carolitertii velocity relocations during NHP were significantly higher $(p<0.01$; Mann-Whitney $\mathrm{U})$ than $P$. duriense relocations. No velocity higher than $1 \mathrm{~m} / \mathrm{s}$ was found to be used by any of the studied species.

Principal component analysis (Figure 6) extracted two principal components (PCs) with eigenvalues $>1$, which explained $67.0 \%$ and $67.6 \%$ of the variance in the data for $P$. duriense and S. carolitertii, respectively. PC1 presented high loadings for velocity $(-0.65)$ and distance to the SHP tailrace $(0.50)$ for $P$. duriense, whereas PC2 loaded positively high on depth (0.67) and substrate $(0.56)$. For S. carolitertii, PC1 also showed higher loadings on the distance to the SHP tailrace $(-0.62)$ and depth (57.9) and PC2 loaded negatively high for velocity $(-0.80)$ and positively high for substrate (0.60). For both species, fish relocations during HP were related to velocity. 
(a)

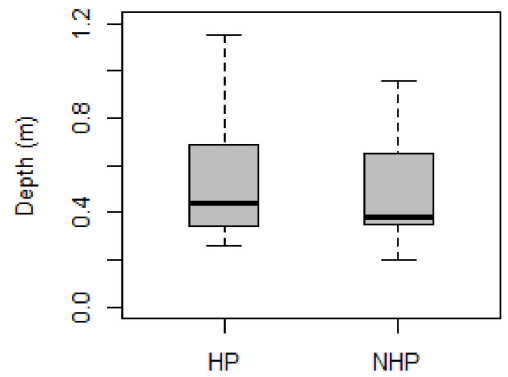

(b)

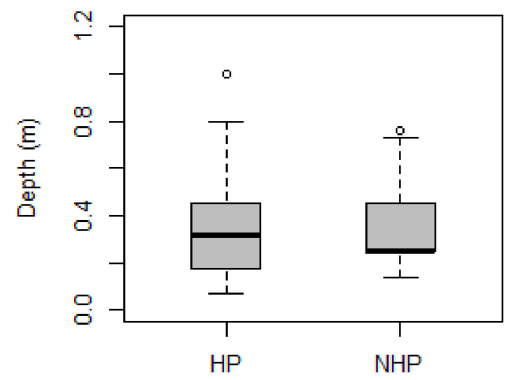

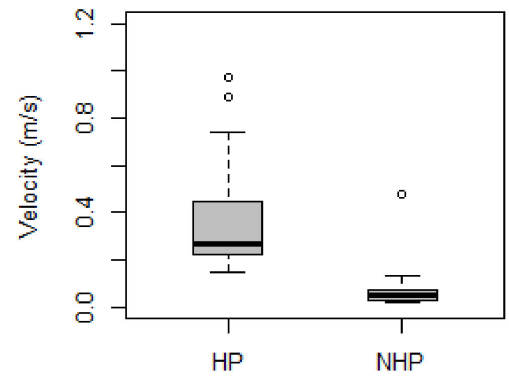

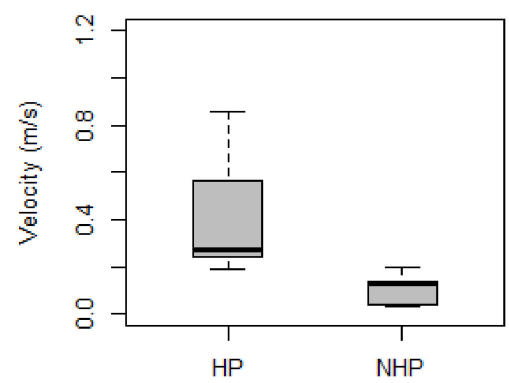

Figure 5. Boxplots of habitat use-depth (m) and velocity (m/s) - for (a) P. duriense and (b) S. carolitertii relocations during HP and NHP occasions.

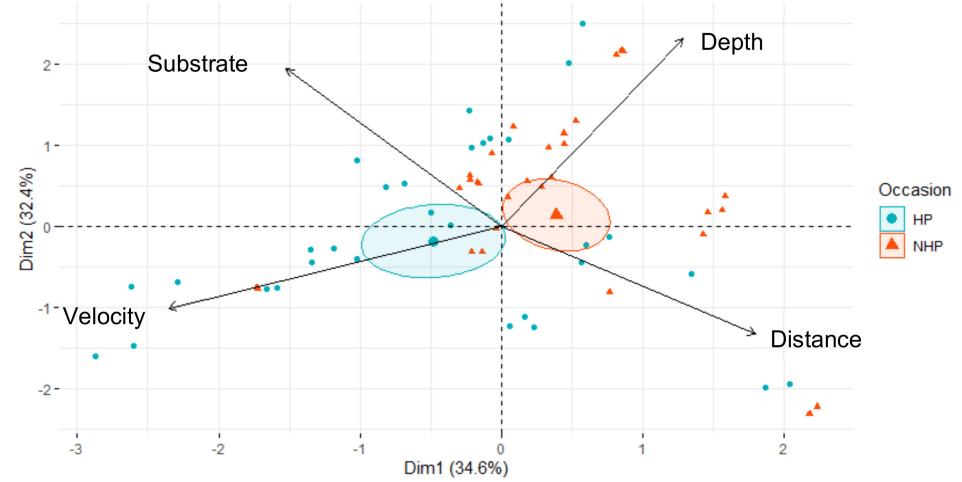

(a)

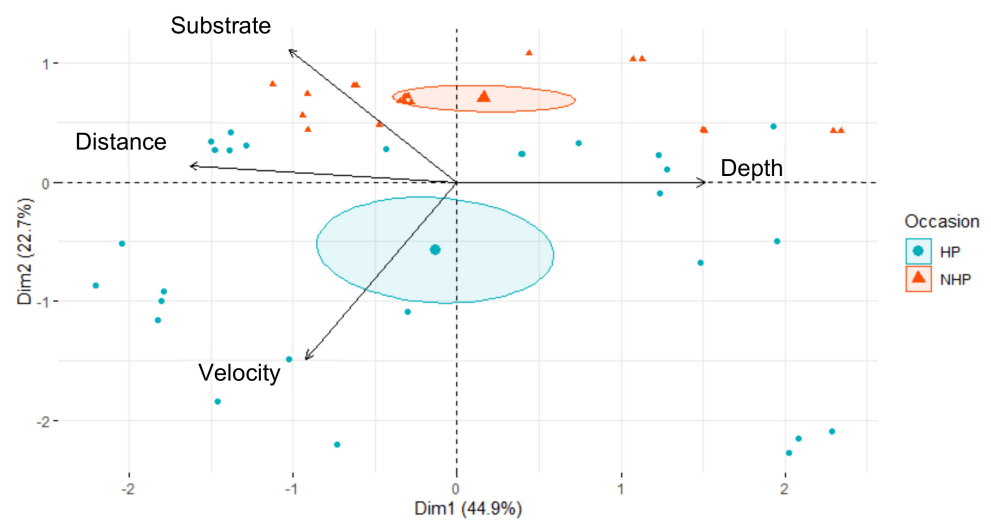

(b)

Figure 6. Principal component analysis (PCA) for (a) P. duriense and (b) S. carolitertii for the environmental variables: velocity, distance (to the SHP tailrace), substrate, and depth. Ellipses (confidence level $=0.95$ ) are graphical representations of the samples at HP and NHP. 
The multivariate analysis of variance yielded an overall significant difference between occasions for $P$. duriense $(\mathrm{F}=13.88, \mathrm{df}=75, p=0.001)$ and $S$. carolitertii $(\mathrm{F}=9.9995, \mathrm{df}=75, p=0.001)$. P. duriense yielded significant differences for distance to the SHP tailrace (chi-squared $=4.5869, \mathrm{df}=1, p=0.03222$ ) (Figure 4a) and velocity (chi-squared $=40.491, \mathrm{df}=1, p<0.001$ ) (Figure 5a). Significant differences occurred only for the velocity variable (chi-squared $=35.6, \mathrm{df}=1, p<0.001$ ) for S. carolitertii (Figure $5 \mathrm{~b}$ ).

\section{Discussion}

The present study focused on the influence of an SHP on the habitat use of Iberian native small-sized cyprinids, the Iberian straight-mouth nase Pseudochondrostoma duriense and the Iberian chub Squalius carolitertii downstream of a SHP, contributing to the first insights on habitat use of these small-sized cyprinids in peaking rivers. Overall, differences in the use of habitat were observed between HP and NHP and among the two studied cyprinids. The number of fish collected in the studied reach was fairly similar for $P$. duriense and S. carolitertii. The former species is larger in size, undertakes seasonal potamodromous migrations and can be found in deeper habitats, with higher flow velocity [55], thus, potentially inhabiting peaking rivers. The association of $P$. duriense and S. carolitertii to high-gradient upstream rivers was reported before $[55,56]$, though other studies have described $P$. duriense to inhabit mid-lower river courses $[57,58]$. Our results come in line with the latest reports [56]. According to other studies conducted in Iberian streams, Squalius spp. occupy a higher position in the water column, enabling feeding on drift, whereas Pseudochondrostoma spp. use the river bed, where they eat organic debris, small invertebrates and microscopic alga [59-61].

Body size and condition factors are two of the most important traits affecting the ecological performance of individuals [62] and susceptibility to displacement by peak flows may decrease with increasing fish size [63,64] and condition factor [21]. Low condition factors have been associated to downstream displacement due to peak flows [21] and also to fish inhabiting river reaches with low flow due to water diversion in SHP [9]. Therefore, highlighting the relation between fitness-related traits and flow magnitude, S. carolitertii with a higher condition factor, were found in HP (see Figure 2), likely pointing out the stress placed by peak flows. Fish with greater condition factor, and likely greater energy reserves, would subsist during HP while fish in the poorest conditions would likely lose their swimming capacity, being susceptible to downstream displacement [65]. In contrast, for P. duriense, no difference was found in the body condition between HP and NHP. The importance of higher body condition to hold positions during HP would be particularly relevant for S. carolitertii due to its use of the mid- to upper water column, where velocities are likely higher. On the other hand, fish with a higher condition factor could have moved longer distances due to their increased swimming capacity, therefore, leaving the studied reach.

S. carolitertii was found to be using the mid-section of the downstream part of the river reach (20 to $50 \mathrm{~m}$ distance of the tailrace) during HP (Figure 4). S. carolitertii, being a water column feeder, would probably benefit from the disturbed area downstream of the SHP tailrace to find food, including prey transported together with the turbined flow. P. duriense limited their movements to an area close to the SHP tailrace, either downstream or upstream the tailrace. P. duriense was possibly adopting a behavioral strategy of moving upstream whenever the SHP would start operation to avoid the peak flow and returning to the initial position when the SHP would cease the turbines. In this marginally disturbed region - the vicinity of the SHP tailrace-fish would profit from well aerated water from the receding peak flow, fundamental for fish survival [66,67], while not being directly exposed to high flow velocity. This artifice suggests a habituation behavior already reported for cyprinids $[68,69]$ and other genera [70]. Furthermore, P. duriense, a bottom-dwelling feeder, would be encouraged to inhabit the area upstream of the SHP tailrace where they could find food supply [61,71].

Locations of both species were associated with velocity, distance to the SHP tailrace, depth and substrate. Other studies have identified water velocity as the most important variable differentiating habitats for these species [55], as well as for other cyprinids in Iberian rivers [72]. Depth has been also reported as the primary parameter influencing habitat use [59], though this may be related to 
the characteristics of studied river reaches, strongly affected by Mediterranean climate and where depth could be important for providing refuge against summer drying [73]. During both HP and NHP, P. duriense tended to occupy areas of higher depth and lower velocity when compared to S. carolitertii. This observation likely reflects the typical habitat used by both species (and related taxa), with S. carolitertii occupying a higher position in the water column of runs, and P. duriense occupying the river bottom of pools. The importance of distance to the SHP tailrace, also contributed to species distribution, highlighting the effect of peak flows in fish habitat selection. The importance of substrate has been pointed out in different studies focused on riverine cyprinids [24], namely during the spawning season [74]. In particular, substrate has been correlated to P. duriense distribution, together with cover and shading [58]. In peaking rivers, substrates seem to be less important to consider with regard to fish selecting habitat, probably because fish are first triggered by environmental variables that are peak-related, like water velocity. Habitat use will likely also result from other biotic and abiotic interactions occurring in the ecosystem, which are harder to define and quantify, such as predation, competition, learned behaviors, and food resources [25]. Additional variables, which are often used in fish distribution models at a local scale, include dissolved oxygen, $\mathrm{pH}$ and conductivity [75], and these variables could be important as well. Furthermore, the effects described here are confined to diurnal behavior, which correspond to our observation window. During the reproductive season for cyprinid species, diel behavior patterns and shifts in habitat use have been reported [76] and therefore assumptions for fish behavior at night could not be made.

Fish were probably unavoidably using areas of higher velocities during the HP occasion. Santos et al. [55] compared microhabitat use for different size-classes of S. carolitertii and P. polylepsis (from the same ecological guild as $P$. duriense). Both species were found using deeper and fast-flowing habitats during winter and spring, but $S$. carolitertii used slower velocities, contrarily to our results where S. carolitertii was found in locations with significantly higher flow velocities than P. duriense during NHP. Other studies associated $P$. duriense with fast-flowing areas in higher and medium courses of rivers [56]. It is likely that the larger size and higher condition factor could have helped S. carolitertii to inhabit faster current waters when compared with P. duriense in our study. In agreement, larger S. carolitertii were found occupying significantly faster flowing areas than smaller individuals [55]. Regardless, there is a lack of studies regarding habitat use for these cyprinids, in particular for P. duriense, despite studies to assess fish passage performance [77,78], or regarding large-scale fish distribution [58]. More studies are needed to validate our results.

It should however be noted that by using a 2D model, the velocity results obtained are depth-averaged, thus vertical variations of velocity and secondary circulation, which also influence habitat use, were not represented and accounted for in this analysis. In more complex flow areas (e.g., behind large boulders or other river flow topology variations) where the flow is 3D, this influence is higher. Turbulence, which is known to influence fish behavior and habitat use [26-28], since predictable flows enhance fish exploratory movements and reduce locomotion energy expenditure, while turbulent flows with chaotic and wide fluctuations in velocity can repel fish [26], was also not included in this study.

The use of telemetry may help to understand what triggers fish movements and their use of particular habitats. It enables studies of longer temporal range and the assessment of the impact of small-scale environmental conditions over large distances within streams [36]. Nevertheless, while interpreting telemetry data, one has to account for potential sources of errors, which may explain the low detection rate identified in this study in comparison with other studies in peaking rivers with rates of $80 \%$ [34] or even higher [79]. With PIT tag technology, the continuous harassment of the fish by the upstream walk of the operator may actually alter the very behavior that one is hoping to monitor. In specific situations, boulder structures in the river bed may isolate the signal between the tagged fish and the operator, and the fish may not be detected, as we believe could have been our case due to the river's substrate (i.e., sections with large boulders) and morphology. The same can occur in deep areas, where the antenna range is not enough to identify a tagged fish on the bottom. Additionally, 
tag rejection could explain the detection rate, though the rejection of the tag has been only reported for $0.05 \%$ of the tagged fish in other studies [80,81], and we did not detect lost tags in the surveyed reach. Otherwise, fish may have moved downstream out of the studied reach, swimming longer distances. Another issue that may have compromised our detection rate is associated with the river ecosystem. Located in a mountainous and remote area, the studied reach harbors the mammal, European otter, with a diet including small-sized fish [54]. We hypothesized that fish would be eaten by the otters and tags would be afterwards excreted in the river banks, and, thus, lost for the accounting.

To our knowledge, this is the first contribution to the state of art of habitat use of small-sized cyprinids in peaking rivers. While a few studies reported the effects of hydropeaking on cyprinids [6], for small-sized bodies studies are almost nonexistent [56]. Nevertheless, data to study habitat use in peaking rivers should also be collected during all stages of the peak event: from upramping, to peak flow and to downramping. However, this is extremely difficult to obtain for small-sized fish, where telemetry technology could be simply unaffordable for a consistent amount of data [36]. Other popular data collection methods to study habitat use such as electrofishing or snorkeling [82] can be dangerous to undertake during a peak event, or at some point impossible due to the flow magnitude.

The effects of hydropeaking reported here at the individual level can cause detrimental effects on metabolism, growth, reproductive potential, and eventually, the condition and survival of fish. Such negative effects may be transferred to the different organization levels, depending on the magnitude and intensity of stress exposure: from individual (fitness condition, growth), to population (abundance) and, ultimately, to community level (relative abundance of fish species) [83,84]; already reported downstream of an SHP in other hydropeaking studies [85]. Therefore, the need to mitigate those impacts is paramount. Additionally, fish communities dominated by riverine cyprinids are more sensitive to hydropeaking than communities dominated by brown trout (Salmo trutta) [86]. Lateral velocity refuges tested in the laboratory environment have proven to be a successful mitigation measure in peaking rivers [30,31]. Preliminary analyses on the use of a lateral refuge $(40 \mathrm{~cm} \mathrm{high;} 40 \mathrm{~cm}$ wide and $50 \mathrm{~cm}$ long) in a river bank downstream of an SHP (Boavida et al., unpublished data) show fish starting to use the refuge c. $10 \mathrm{~min}$ after the turbines start operation, with larger adults appearing after the turbine discharge reached half of its maximum capacity. Nevertheless, further analyses have to be performed to assess the effectiveness of this mitigation measure to protect small-sized cyprinids in the field and, accordingly, guarantee the sustainability of the population and community. Environmental flows can also be a powerful measure to mitigate those impacts [86] by minimizing the flow ratio (difference between the base and peak flow), and, otherwise, mimic the natural flow regime and its inter-annual flow variability, which is the key factor controlling the ecological health and the natural abiotic structure of riverine ecosystems [87]. What we know so far is that, with respect to hydropeaking, mitigation measures are a proven tool to decrease the level of impact [88]. However, since impacts are site-specific, a prior assessment is unavoidable most of the time. Therefore, studies regarding habitat use in peaking rivers comprising different species and different river reaches will strongly contribute to help in the selection and design of those mitigation measures.

Author Contributions: Conceptualization, I.B. and F.G.; data curation, I.B., F.A. and A.Q.; formal analysis, I.B., F.A. and M.M.P.; funding acquisition, I.B., A.P. and F.G.; investigation, I.B., F.A. and F.G.; methodology, I.B., M.J.C. and F.G.; project administration, A.P.; resources, I.B.; supervision, A.P. and F.G.; validation, I.B., M.J.C. and F.G.; visualization, I.B., F.A., M.J.C., A.Q. and F.G.; writing-original draft, Isabel Boavida; writing-review and editing, I.B., M.J.C., A.Q., M.M.P., A.P. and F.G. All authors have read and agreed to the published version of the manuscript.

Funding: This research has received funding from the European Union's Horizon 2020 research and innovation programme under grant agreement No. 727830, http://www.fithydro.eu/. Filipa Ambrósio was supported by a Scientific Fellowship from CERIS, Civil Engineering Research and Innovation for Sustainability for boosting and supporting the research. 
Acknowledgments: The authors would like to thank Hidroerg for providing the HPP operation data of Bragado SHP and for supporting the fieldwork. Acknowledgments are also due to Raul Costa for a tremendous and valuable help during field work. The Portuguese Institute for Nature Conservation and Forest (ICNF) provided the necessary fishing and handling permits and the Direção Geral de Alimentação e Veterinária (DGAV) provided the project authorization.

Conflicts of Interest: The authors declare no conflict of interest.

\section{References}

1. Zarfl, C.; Lumsdon, A.E.; Berlekamp, J.; Tydecks, L.; Tockner, T. A global boom in hydropower dam construction. Aquat. Sci. 2014, 77, 161-170. [CrossRef]

2. IHA. Hydropower Status Report: Sector Trends and Insights; IHA: London, UK, 2018.

3. Nilsson, C.; Reidy, C.A.; Dynesius, M.; Revenga, C. Fragmentation and flow regulation of the world's large river systems. Science 2005, 308, 405-408. [CrossRef] [PubMed]

4. Schwarz, U. Hydropower Pressure on European Rivers. The Story in Numbers; WWF, RiverWatch, EuroNatur, GEOTA: Gland, Switzerland, 2019.

5. Demirbas, A. Focus on the World: Status and Future of Hydropower. Energy Sources Part B Econ. Plan. Policy 2007, 2, 237-242. [CrossRef]

6. Capra, H.; Plichard, L.; Bergé, J.; Pella, H.; Ovidio, M.; McNeil, E.; Lamouroux, N. Fish habitat selection in a large hydropeaking river: Strong individual and temporal variations revealed by telemetry. Sci. Total Environ. 2017, 578, 109-120. [CrossRef] [PubMed]

7. Korman, J.; Campana, S.E. Effects of Hydropeaking on Nearshore Habitat Use and Growth of Age-0 Rainbow Trout in a Large Regulated River. Trans. Am. Fish. Soc. 2009, 138, 76-87. [CrossRef]

8. Pragana, I.; Boavida, I.; Cortes, R.; Pinheiro, A. Hydropower Plant Operation Scenarios to Improve Brown Trout Habitat. River Res. Appl. 2017, 33, 364-376. [CrossRef]

9. Benejam, L.; Saura-Mas, S.; Bardina, M.; Solá, C.; Munné, A.; García-Berthou, E. Ecological impacts of small hydropower plants on headwater stream fish: From individual to community effects. Ecol. Freshw. Fish 2016, 25, 295-306. [CrossRef]

10. Lange, K.; Meier, P.; Trautwein, C.; Schmid, M.; Robinson, C.T.; Weber, C.; Brodersen, J. Basin-scale effects of small hydropower on biodiversity dynamics. Front. Ecol. Environ. 2018, 16, 397-404. [CrossRef]

11. Anderson, D.; Moggridge, H.; Warren, P.; Shucksmith, J. The impacts of "run-of-river" hydropower on the physical and ecological condition of rivers. Water Environ. J. 2015, 29, 268-276. [CrossRef]

12. Kibler, K.M.; Tullos, D.D. Cumulative biophysical impact of small and large hydropower development in $\mathrm{Nu}$ River, China. Water Resour. Res. 2013, 49, 3104-3118. [CrossRef]

13. Cushman, R.M. Review of Ecological Effects of Rapidly Varying Flows Downstream from Hydroelectric Facilities. N. Am. J. Fish. Manag. 1985, 5, 330-339. [CrossRef]

14. Young, P.S.; Cech, J.J.; Thompson, L.C. Hydropower-related pulsed-flow impacts on stream fishes: A brief review, conceptual model, knowledge gaps, and research needs. Rev. Fish Biol. Fish. 2011, 21, 713-731. [CrossRef]

15. Costa, M.J.; Fuentes-Pérez, J.F.; Boavida, I.; Tuhtan, J.A.; Pinheiro, A.N. Fish under pressure: Examining behavioural responses of Iberian barbel under simulated hydropeaking with instream structures. PLoS ONE 2019, 14, e021. [CrossRef] [PubMed]

16. Rocaspana, R.; Aparicio, E.; Vinyoles, D.; Palau, A. Effects of pulsed discharges from a hydropower station on summer diel feeding activity and diet of brown trout (Salmo trutta Linnaeus 1115, 1758) in an Iberian stream. J. Appl. Ichthyol. 2016, 32, 190-197. [CrossRef]

17. Puffer, M.; Berg, O.K.; Huusko, A.; Vehanen, T.; Einum, S. Effects of intra- and interspecific competition and hydropeaking on growth of juvenile Atlantic salmon (Salmo salar). Ecol. Freshw. Fish 2017, 26, 99-107. [CrossRef]

18. Vollset, K.W.; Skoglund, H.; Wiers, T.; Barlaup, B. Effects of hydropeaking on the spawning behaviour of Atlantic salmon Salmo salar and brown trout Salmo trutta. J. Fish Biol. 2016, 88, 2236-2250. [CrossRef]

19. Boavida, I.; Santos, J.M.J.M.; Ferreira, T.; Pinheiro, A. Barbel habitat alterations due to hydropeaking. J. Hydro-Environ. Res. 2015, 9, 237-247. [CrossRef] 
20. Auer, S.; Zeiringer, B.; Führer, S.; Tonolla, D.; Schmutz, S. Effects of river bank heterogeneity and time of day on drift and stranding of juvenile European grayling (Thymallus thymallus L.) caused by hydropeaking. Sci. Total Environ. 2017, 575, 1515-1521. [CrossRef]

21. Boavida, I.; Harby, A.; Clarke, K.D.; Heggenes, J. Move or stay: Habitat use and movements by Atlantic salmon parr (Salmo salar) during induced rapid flow variations. Hydrobiologia 2017, 785, 261-275. [CrossRef]

22. Halleraker, J.H.; Saltveit, S.J.; Harby, A.; Arnekleiv, J.V.; Fjeldstad, H.-P.; Kohler, B. Factors influencing stranding of wild juvenile brown trout (Salmo trutta) during rapid and frequent flow decreases in an artificial stream. River Res. Appl. 2003, 19, 589-603. [CrossRef]

23. Beecher, H.A.; Caldwell, B.A.; DeMond, S.B. Evaluation of Depth and Velocity Preferences of Juvenile Coho Salmon in Washington Streams. N. Am. J. Fish. Manag. 2002, 22, 785-795. [CrossRef]

24. Boavida, I.; Santos, J.M.J.M.; Pinheiro, A.N.; Ferreira, M.T. Fish habitat availability simulations using different morphological variables. Limnetica 2011, 30, 393-404.

25. Rosenfeld, J. Assessing the Habitat Requirements of Stream Fishes: An Overview and Evaluation of Different Approaches. Trans. Am. Fish. Soc. 2003, 132, 953-968. [CrossRef]

26. Liao, J.C. A review of fish swimming mechanics and behaviour in altered flows. Philos. Trans. R. Soc. B Biol. Sci. R. Soc. 2007, 362, 1973-1993. [CrossRef]

27. Tritico, H.M.; Cotel, A.J. The effects of turbulent eddies on the stability and critical swimming speed of creek chub (Semotilus atromaculatus). J. Exp. Biol. 2010, 213, 2284-2293. [CrossRef]

28. Lacey, R.W.J.; Neary, V.S.; Liao, J.C.; Enders, E.C.; Tritico, H.M. The ipos framework: Linking fish swimming performance in altered flows from laboratory experiments to rivers. River Res. Appl. 2012, 28, 429-443. [CrossRef]

29. Santos, J.M.; Rivaes, R.; Boavida, I.; Branco, P. Structural microhabitat use by endemic cyprinids in a Mediterranean-type river: Implications for restoration practices. Aquat. Conserv. Mar. Freshw. Ecosyst. 2017, 28, 26-36. [CrossRef]

30. Costa, M.J.; Pinheiro, A.N.; Boavida, I. Habitat Enhancement Solutions for Iberian Cyprinids Affected by Hydropeaking: Insights from Flume Research. Sustainability 2019, 11, 6998. [CrossRef]

31. Ribi, J.-M.; Boillat, J.-L.; Peter, A.; Schleiss, A.J. Attractiveness of a lateral shelter in a channel as a refuge for juvenile brown trout during hydropeaking. Aquat. Sci. 2014, 76, 527-541. [CrossRef]

32. Taylor, M.K.; Cooke, S.J. Repeatability of movement behaviour in a wild salmonid revealed by telemetry. J. Fish Biol. 2014, 84, 1240-1246. [CrossRef]

33. D'Arcy, J.; Kelly, S.; McDermott, T.; Hyland, J.; Jackson, D.; Bolton-Warberg, M. Assessment of PIT tag retention, growth and post-tagging survival in juvenile lumpfish, Cyclopterus lumpus. Anim. Biotelemetry 2020, 8, 1-9. [CrossRef]

34. Roussel, J.-M.M.; Haro, A.; Cunjak, R.A.A. Field test of a new method for tracking small fishes in shallow rivers using passive integrated transponder (PIT) technology. Can. J. Fish. Aquat. Sci. 2000, 57, 1326-1329. [CrossRef]

35. Leclercq, E.; Zerafa, B.; Brooker, A.J.; Davie, A.; Migaud, H. Application of passive-acoustic telemetry to explore the behaviour of ballan wrasse (Labrus bergylta) and lumpfish (Cyclopterus lumpus) in commercial Scottish salmon sea-pens. Aquaculture 2018, 495, 1-12. [CrossRef]

36. Rogers, K.; White, G. Analysis of movement and habitat use from telemetry data. In Analysis and Interpretation of Freshwater Fisheries Data; Guy, S., Brown, M., Eds.; American Fisheries Society: Bethesda, MD, USA, 2007; pp. 625-676.

37. Doadrio. Atlas y Libro Rojo de los Peces Continentales de España. Dirección General de Conservación de la Naturaléza Museo Nacional de Ciencias Naturales; Ministerio de Medio Ambiente: Madrid, Spain, 2001.

38. Strahler, A.N. Quantitative analysis of watershed geomorphology. Trans. Am. Geophys. Union 1957, 38, 913-920. [CrossRef]

39. Bovee, K.D.; Lamb, B.L.; Bartholow, J.M.; Stalnaker, C.B.; Taylor, J.; Henriksen, J. Stream Habitat Analysis using the Instream Flow Incremental Methodology; U.S. Geological Survey, Biological Resources Division: Reston, VA, USA, 1998; p. 131.

40. Ross, M.J.; McCormick, J.H. Effects of External Radio Transmitters on Fish. Progress. Fish Culturist 1981, 43, 67-72. [CrossRef] 
41. Kelly, B.B.; Cary, J.B.; Smith, A.D.; Pregler, K.C.; Kim, S.; Kanno, Y. Detection Efficiency of a Portable PIT Antenna for Two Small-Bodied Fishes in a Piedmont Stream. N. Am. J. Fish. Manag. 2017, 37, 1362-1369. [CrossRef]

42. CEN. Water Quality: Sampling of Fish with Electricity. European Standard EN 14011; European Committee for Standardization: Brussels, Belgium, 2003.

43. INAG. Manual Para a Avaliação Biológica da Qualidade da Água em Sistemas Fluviais Segundo a Directiva Quadro da Água: Protocolo de Amostragem e Análise Para a Fauna Piscícola; Ministério do Ambiente, do Ordenamento do Território e do Desenvolvimento Regional, Instituto da Água, I.P: Lisbon, Portugal, 2008.

44. Trincão, M. Aplicabilidade da Ferramenta COSH-Tool no Estudo do Fenómeno do Hydropeaking em Pequenos Aproveitamentos Hidroelétricos Localizados em Portugal Continental; Instituto Superior Técnico, University of Lisbon: Lisbon, Portugal, 2018.

45. Pearson, K. On lines and planes of closest fit to systems of points in space. London, Edinburgh, Dublin Philos. Mag. J. Sci. 1901, 2, 559-572. [CrossRef]

46. Kassambara, A.; Mundt, F. Extract and Visualize the Results of Multivariate Data Analyses. Package 'factoextra'; CRAN: Vienna, Austria, 2017; p. 77. Available online: https://cran.r-project.org/web/packages/factoextra/ index.html (accessed on 9 September 2020).

47. Anderson, M.J.; Robinson, J. Permutation tests for linear models. Aust. N. Z. J. Stat. 2001, 43, 75-88. [CrossRef]

48. Walters, K.; Coen, L.D. A comparison of statistical approaches to analyzing community convergence between natural and constructed oyster reefs. J. Exp. Mar. Biol. Ecol. 2006, 330, 81-95. [CrossRef]

49. Oksanen, J.; Blanchet, F.G.; Friendly, M.; Kindt, R.; Legendre, P.; McGlinn, D.; Minchin, P.R.; O’Hara, R.B.; Simpson, G.L.; Solymos, P.; et al. Community Ecology Package. Package 'Vegan'; CRAN: Vienna, Austria, 2019; p. 296. Available online: https://cran.r-project.org/web/packages/vegan/index.html (accessed on 9 September 2020).

50. Venables, W.N.; Smith, D.M. An Introduction to R Notes on R: A Programming Environment for Data Analysis and Graphics; CRAN: Vienna, Austria, 2019; p. 105. Available online: https://cran.r-project.org/doc/manuals/rrelease/R-intro.pdf (accessed on 9 September 2020).

51. Wickham, H.; Chang, W.; Henry, L.; Pederson, T.L.; Takahashi, K.; Wilke, C.; Woo, K.; Yutani, H.; Dunnington, D. Create Elegant Data Visualisations Using the Grammar of Graphics. Package 'ggplot2'; CRAN: Vienna, Austria, 2020; p. 277. Available online: https://cran.r-project.org/web/packages/ggplot2/index.html (accessed on 9 September 2020).

52. Horikoshi, M.; Tang, Y.; Dickey, A.; Grenié, M.; Thompson, R.; Selzer, L.; Strbenac, D.; Voronin, K. Data Visualization Tools for Statistical Analysis Results. Package 'ggfortify'; CRAN: Vienna, Austria, 2020; p. 85. Available online: https://cran.r-project.org/web/packages/ggfortify/index.html (accessed on 9 September 2020).

53. Wei, T.; Simko, V.; Levy, M.; Xie, Y.; Jin, Y.; Zemla, J. Visualization of a Correlation Matrix. Package 'corrplot'; CRAN: Vienna, Austria, 2017; p. 18.

54. Pedroso, N.M.; Sales-Luís, T.; Santos-Reis, M. The Eurasian otter Lutra lutra (Linnaeus, 1758) in Portugal. Munibe Monogr. Nat. Ser. 2014, 3, 133-144. [CrossRef]

55. Santos, J.; Godinho, F.; Ferreira, M. Microhabitat use by Iberian nase Chondrostoma polylepis and Iberian chub Squalius carolitertii in three small streams, north-west Portugal. Ecol. Freshw. Fish 2004, 13, 223-230. [CrossRef]

56. Santos, J.M.; Reino, L.; Porto, M.; Oliveira, J.; Pinheiro, P.; Almeida, P.R.; Cortes, R.; Ferreira, M.T. Complex size-dependent habitat associations in potamodromous fish species. Aquat. Sci. 2010, 73, 233-245. [CrossRef]

57. Carmona, J.A.; Doadrio, I.; Márquez, A.L.; Real, R.; Hugueny, B.; Vargas, J.M. Distribution patterns of indigenous freshwater fishes in the Tagus River basin, Spain. Environ. Biol. Fishes 1999, 54, 371-387. [CrossRef]

58. Ferreira, M.T.; Sousa, L.; Santos, J.M.; Reino, L.; Oliveira, J.; Almeida, P.R.; Cortes, R.V. Regional and local environmental correlates of native Iberian fish fauna. Ecol. Freshw. Fish 2007, 16, 504-514. [CrossRef]

59. Grossman, G.; Sostoa, A.; Freeman, M.; Lobon-Cerviá, J. Microhabitat use in a mediterranean riverine fish assemblage. Fishes of the upper Matarraña. Oecologia 1987, 73, 501-512. [CrossRef] [PubMed]

60. Grossman, G.; Freeman, M. Microhabitat use in a stream fish assemblage. J. Zool. 1987, 212, 151-176. [CrossRef] 
61. Sánchez-Hernández, J.; Vieira-Lanero, R.; Servia, M.J.; Cobo, F. Feeding habits of four sympatric fish species in the Iberian Peninsula: Keys to understanding coexistence using prey traits. Hydrobiologia 2011, 667, 119-132. [CrossRef]

62. Murphy, C.A.; Casals, F.; Solà, C.; Caiola, N.; Sostoa, A.; García-Berthou, E. Efficacy of population size structure as a bioassessment tool in freshwaters. Ecol. Indic. 2013, 34, 571-579. [CrossRef]

63. Heggenes, J. Effects of Short-Term Flow Fluctuations on Displacement of, and Habitat Use by, Brown Trout in a Small Stream. Trans. Am. Fish. Soc. 1988, 117, 336-344. [CrossRef]

64. Thompson, L.C.; Cocherell, S.A.; Chun, S.N.; Cech, J.J.; Klimley, A.P. Longitudinal movement of fish in response to a single-day flow pulse. Environ. Biol. Fishes 2011, 90, 253-261. [CrossRef]

65. Flodmark, L.E.W.; Forseth, T.; L'Abee-Lund, J.H.; Vøllestad, L.A. Behaviour and growth of juvenile brown trout exposed to fluctuating flow. Ecol. Freshw. Fish 2006, 15, 57-65. [CrossRef]

66. Kramer, D.L. Dissolved oxygen and fish behavior. Environ. Biol. Fishes 1987, 18, 81-92. [CrossRef]

67. Beamish, F.W.H.; Sa-Ardrit, P.; Tongnunui, S. Habitat characteristics of the cyprinidae in small rivers in Central Thailand. Environ. Biol. Fishes 2006, 76, 237-253. [CrossRef]

68. Costa, M.J.; Boavida, I.; Almeida, V.; Cooke, S.J.; Pinheiro, A.N. Do artificial velocity refuges mitigate the physiological and behavioural consequences of hydropeaking on a freshwater Iberian cyprinid? Ecohydrology 2018, 11, e1983. [CrossRef]

69. Jesus, J.; Amorim, M.C.P.; Fonseca, P.J.; Teixeira, A.; Natário, S.; Carrola, J.; Varandas, S.; Pereira, L.T.; Cortes, R.V. Acoustic barriers as an acoustic deterrent for native potamodromous migratory fish species. J. Fish Biol. 2019, 95, 247-255. [CrossRef]

70. Mickle, M.F.; Higgs, D.M. Integrating techniques: A review of the effects of anthropogenic noise on freshwater fish. Can. J. Fish. Aquat. Sci. 2018, 75, 1534-1541. [CrossRef]

71. Carmona, J.; Doadrio, I. Threatened fishes of the world: Leuciscus carolitertii Doadrio 1, 1988 (Cyprinidae). Environ. Biol. Fishes 2000, 57, 96. [CrossRef]

72. Rincón, P.A.P.; Barrachina, P.; Bernat, Y. Microhabitat use by $0+$ juvenile cyprinids during summer in a Mediterranean river. Arch. Hydrobiol. 1992, 125, 323-337.

73. Godinho, F.N.; Ferreira, M.T.; Santos, J.M. Variation in fish community composition along an Iberian river basin from low to high discharge: Relative contributions of environmental and temporal variables. Ecol. Freshw. Fish 2000, 9, 22-29. [CrossRef]

74. Boavida, I.; Jesus, J.B.; Pereira, V.; Santos, C.; Lopes, M.; Cortes, R.V. Fulfilling spawning flow requirements for potamodromous cyprinids in a restored river segment. Sci. Total Environ. 2018, 635, 567-575. [CrossRef]

75. Bain, M.; Robinson, C. Structure, Performance, and Assumptions of Riverine Habitat Suitability Index Models; Aquatic Resources Research Series 88-3; Alabama Cooperative Fish and Wildlife Research Unit: Auburn, AL, USA, 1988.

76. Lucas, M.C.; Frear, P.A. Effects of a flow-gauging weir on the migratory behaviour of adult barbel, a riverine cyprinid. J. Fish Biol. 1997, 50, 382-396. [CrossRef]

77. Sanz-Ronda, F.J.; Bravo-Córdoba, F.J.; Fuentes-Pérez, J.F.; Castro-Santos, T.R. Ascent ability of brown trout, Salmo trutta, and two Iberian cyprinids-Iberian barbel, Luciobarbus bocagei, and northern straight-mouth nase, Pseudochondrostoma duriense-In a vertical slot fishway. Knowl. Manag. Aquat. Ecosyst. 2016, 417, 10. [CrossRef]

78. Sanz-Ronda, F.J.; Ruiz-Legazpi, J.; Bravo-Córdoba, F.J.; Makrakis, S.; Castro-Santos, T. Sprinting performance of two Iberian fish: Luciobarbus bocagei and Pseudochondrostoma duriense in an open channel flume. Ecol. Eng. 2015, 83, 61-70. [CrossRef]

79. Enders, E.; Stickler, M.; Pennell, C.; Cote, D.; Alfredson, K.; Scruton, D.A. Variations in distribution and mobility of Atlantic salmon parr during winter in a small, steep river. Hydrobiologia 2008, 609, 37-44. [CrossRef]

80. Skov, C.; Brodersen, J.; Bronmark, C.; Hansson, L.-A.; Hertonsson, P.; Nilsson, P.A. Evaluation of PIT-tagging in cyprinids. J. Fish Biol. 2005, 67, 1195-1201. [CrossRef]

81. Das Mahapatra, K.; Gjerde, B.; Reddy, P.V.G.K.; Sahoo, M.; Jana, R.K.; Saha, J.N.; Rye, M. Tagging: On the use of passive integrated transponder (PIT) tags for the identification of fish. Aquac. Res. 2001, 32, 47-50. [CrossRef]

82. Plichard, L.; Capra, H.; Mons, R.; Pella, H.; Lamouroux, N. Comparing electrofishing and snorkelling for characterizing fish assemblages over time and space. Can. J. Fish. Aquat. Sci. 2017, 74, 75-86. [CrossRef] 
83. Odum, E. Fundamentals of ecology. Sci. Educ. 1954, 38, 314. [CrossRef]

84. Bain, M. Hydropower Operations and Environmental Conservation: St. Mary's River, Ontario and Michigan, Canada and USA. Ithaca; International Lake Superior Board of Control: Washington, DC, USA, 2007.

85. Schmutz, S.; Bakken, T.H.; Friedrich, T.; Greimel, F.; Harby, A.; Jungwirth, M.; Melcher, A.; Unfer, G.; Zeiringer, B. Response of Fish Communities to Hydrological and Morphological Alterations in Hydropeaking Rivers of Austria. River Res. Appl. 2015, 31, 919-930. [CrossRef]

86. Boavida, I.; Caetano, L.; Pinheiro, A.N. E-flows to reduce the hydropeaking impacts on the Iberian barbel (Luciobarbus bocagei) habitat. An effectiveness assessment based on the COSH Tool application. Sci. Total Environ. 2020, 699, 134209. [CrossRef]

87. Poff, N.L.; Allan, J.D.; Bain, M.B.; Karr, J.R.; Prestegaard, K.L.; Ritcher, E.S.; Sparks, R.E.; Stromberg, J.C. The natural flow regime. Bioscience 1997, 47,769-784. [CrossRef]

88. Bruder, A.; Tonolla, D.; Schweizer, S.P.; Vollenweider, S.; Langhans, S.D.; Wüest, A. A conceptual framework for hydropeaking mitigation. Sci. Total Environ. 2016, 568, 1204-1212. [CrossRef] [PubMed]

(C) 2020 by the authors. Licensee MDPI, Basel, Switzerland. This article is an open access article distributed under the terms and conditions of the Creative Commons Attribution (CC BY) license (http://creativecommons.org/licenses/by/4.0/). 